Jurnal Ilmu Sosial dan Pendidikan (JISIP)

Vol. 5 No. 3 Juli 2021

Terakreditasi Peringkat 5 (No. SK: 85/M/KPT/2020)

e-ISSN : 2656-6753, p-ISSN: 2598-9944

DOI: 10.36312/jisip.v5i3.2151 /http://ejournal.mandalanursa.org/index.php/JISIP/index

\title{
Analisis Yuridis Kewenangan Perawat Dalam Pengobatan Bekam Pada Praktik Keperawatan Mandiri
}

\author{
${ }^{1}$ Gerardus Gegen, ${ }^{2}$ Aris Prio Agus Santoso \\ ${ }^{1}$ STIH Pelopor Bangsa Depok, ${ }^{2}$ Universitas Duta Bangsa Surakarta \\ ${ }^{1}$ gerardusgegen@gmail.com, ${ }^{2}$ arisprio_santoso@udb.ac.id
}

\begin{tabular}{l}
\hline Article Info \\
Article history: \\
Article Accepted: 28 June 2021 \\
Publication : 11 July 2021
\end{tabular}

\section{Keywords:}

nursing authority, cupping treatment, independent nursing practice.

\begin{abstract}
In providing cupping treatment, health workers must apply patient safety so that malpractice does not occur, because in this digital era everything suspected of malpractice has been widely glimpsed by justice enforcers considering the presence of complementary therapies currently still causing controversy about ethical or not when applied in nursing services. In addition, the standard operating procedures for complementary-alternative services have not been clearly described. The problem in this study is how the authority of nurses in cupping treatment in independent nursing practice, and how the legal protection of cupping treatment in independent nursing practice This research method uses a normative juridical approach, with secondary data collection. To find out whether there is a synchronization between the applicable regulations and the practice in the field. The data obtained were analyzed qualitatively. Based on the results of the study, it was found that nurses have the authority to perform cupping treatment obtained from non-formal education as long as the nurse has competence in the field in question and this authority is also strengthened by the existence of authority in limited circumstances. Nurses who perform cupping get preventive legal protection, which is protected by state institutions through laws and regulations that apply to nursing practitioners.
\end{abstract}

\begin{tabular}{l}
\hline Article Info \\
Article history: \\
Article Accepted: 28 Juni 2021 \\
Publication : 11 July 2021
\end{tabular}

\begin{tabular}{l}
\hline Abstrak \\
Dalam memberikan pengobatan bekam tenaga kesehatan harus menerapkan \\
patient safety agar tidak terjadi malpraktik, karena di era digital ini segala sesuatu \\
yang dicurigai malpraktik sudah banyak dilirik oleh para penegak keadilan \\
mengingat hadirnya terapi komplementer saat ini masih menimbulkan \\
kontroversial tentang etis tidaknya apabila diterapkan dalam layanan \\
keperawatan. Di samping itu batasan standar prosedur operasional pada \\
pelayanan komplementer-alternatif juga belum terdeskripsi secara jelas. \\
Permasalahan dalam penelitian ini adalah bagaimana kewenangan perawat dalam \\
pengobatan bekam pada praktik keperawatan mandiri, dan bagaimana \\
perlindugan hukum pengobatan bekam pada praktik keperawatan mandiri \\
Metode penelitian ini menggunakan pendekatan yuridis normatif, dengan \\
pengumpulan data sekunder. Untuk mengetahui apakah ada sinkronisasi antara \\
peraturan yang berlaku dengan praktik di lapangan. Data yang diperoleh \\
dianalisis secara kualitatif. Berdasarkan hasil penelitian ditemukan bahwa \\
perawat memiliki kewenangan dalam melakukan pengobatan bekam yang \\
diperoleh dari pendidikan non formal asalkan perawat tersebut memiliki \\
kompetensi di bidang yang dimaksud dan kewenangan tersebut diperkuat pula \\
dengan adanya kewenangan dalam keadaan keterbatasan. Perawat yang \\
melakukan bekam mendapatkan pengayoman hukum secara preventif yaitu \\
dilindungi oleh lembaga-lembaga negara melalui peraturan perundang-undangan \\
yang berlaku bagi pelaksana keperawatan.
\end{tabular}

This is an open access article under the Lisensi Creative Commons Atribusi-BerbagiSerupa 4.0 Internasional

\section{Keywords:}

kewenangan perawat, pengobatan bekam, praktik keperawatan mandiri.

\author{
Corresponding Author: \\ ${ }^{1}$ Gerardus Gegen \\ ${ }^{1}$ STIH Pelopor Bangsa Depok, ${ }^{2}$ Universitas Duta \\ Bangsa Surakarta \\ Email: gerardusgegen@gmail.com
}




\section{PENDAHULUAN}

\subsection{Latar Belakang}

Kesehatan merupakan hak asasi manusia dan salah satu unsur kesejahteraan yang harus diwujudkan negara sesuai dengan cita-cita bangsa Indonesia sebagaimana dimaksud dalam Pancasila dan Pembukaan UUD (1945). Oleh karena itu, setiap kegiatan dan upaya untuk meningkatkan derajat kesehatan masyarakat yang setinggi-tingginya dilaksanakan berdasarkan prinsip non diskriminatif, partisipatif, perlindungan, dan berkelanjutan yang sangat penting artinya bagi peningkatan ketahanan dan daya saing bangsa, pembentukan sumber daya manusia Indonesia, dan pembangunan nasional.

Salah satu penyelenggaraan upaya kesehatan adalah melalui pengobatan komplementer dan alternatif. Karena perkembangan terapi komplementer akhir-akhir ini menjadi sorotan banyak negara. Pengobatan komplementer dan alternatif menjadi bagian penting dalam pelayanan kesehatan misal di Amerika Serikat dan negara lainnya. Estimasi di Amerika Serikat 627 juta orang adalah pengguna terapi alternatif dan 386 juta orang yang mengunjungi praktik konvensional. Data lain menyebutkan terjadi peningkatan jumlah pengguna terapi komplementer di Amerika dari 33\% pada tahun 1991 menjadi 42\% di tahun 1997.

Menurut Survei Sosial Ekonomi Nasional (SUSENAS) tahun 2001 sebanyak 57,7\% penduduk Indonesia melakukan pengobatan sendiri tanpa bantuan medis, 31,2\% di antaranya menggunakan tanaman obat tradisional dan 9,8\% memilih cara pengobatan tradisional lainnya.

Dari tinjauan terhadap RPJMN (Rencana Pembangunan Jangka Menengah) 20152019 tampak tidak ditemukan secara spesifik dasar pembangunan kesehatan. Dalam RPJMN tersebut upaya promotif dan preventif masih kurang mendapat penekanan yang saksama. Hal ini membuktikan bahwa masih lemahnya penguatan upaya kesehatan masyarakat.

Praktik keperawatan mandiri merupakan salah satu bentuk upaya penyelenggaraan kesehatan perorangan. Dengan hadirnya praktik keperawatan mandiri, diharapkan upaya preventif dan promotif dapat menjadi lebih baik untuk mengatasi berbagai masalah kesehatan yang ada di masyarakat. Pengobatan komplementer-alternatif merupakan bagian dari ilmu keperawatan holistik yang mencakup bio-psiko-sosio-spiritual yang ditujukan kepada individu, keluarga, dan masyarakat baik sakit maupun sehat yang mencakup seluruh proses kehidupan manusia.

Semakin meningkatnya peminatan masyarakat dengan pengobatan komplementeralternatif, beberapa perawat di daerah-daerah mulai melakukan pengobatan komplementeralternatif pada praktik keperawatan mandiri.

Berkaca dari maraknya malpraktik pengobatan komplementer-alternatif, disebabkan antara lain oleh tiadanya peraturan tegas dari pemerintah. Terutama minimnya pengawasan praktik, ditambah belum adanya undang-undang yang secara jelas mendeskripsikan mengenai pengobatan komplementer-alternatif, dan mengingat lingkup praktik perawat yang masih minim, bisa mengakibatkan terjadinya risiko malpraktik. Pidana dalam pengobatan komplementer-alternatif bisa terjadi di mana saja dan kapan saja apabila perawat telah lalai, tidak mengantongi izin/ lisensi yang jelas, tidak memiliki kompetensi, dan melanggar batas kewenanganya.

Bekam merupakan salah satu pelayanan kesehatan tradisional yang sedang berkembang di masyarakat Indonesia. Pelayanan kesehatan tradisional ini merupakan salah satu perawatan kesehatan tertua di dunia: berusia ribuan tahun dan telah dipraktikkan oleh berbagai macam peradaban besar kuno di dunia, termasuk Mesir, Persia, Babilonia, Cina, India, Yunani dan Romawi. Oleh karena itu, tidak mengherankan jika bekam diminati oleh semua kalangan.

Di Indonesia, orang yang memanfaatkan kesehatan tradisional (kestrad) cukup banyak. Dalam survey Riset Kesehatan Dasar (RKD) 2013, didapatkan 30,4\% keluarga di Indonesia memanfaatkan pelayanan kestrad (yankestrad). Adapun dalam RKD tahun 2018 didapatkan $31,4 \%$ orang pernah memanfaatkan pelayanan yankestrad. Dari yang pernah memanfaatkan 
yankestrad, 98,5\% memanfaatkan pelayanan penyehat tradisional (hattra). Jenis upaya kestrad yang dimanfaatkan terbanyak $(65,3 \%)$ adalah keterampilan manual yang di dalamnya termasuk bekam.

Dalam memberikan pengobatan bekam tenaga kesehatan harus menerapkan patient safety agar tidak terjadi malpraktik, karena di era digital ini segala sesuatu yang dicurigai malpraktik sudah banyak dilirik oleh para penegak keadilan. Seperti yang terjadi pada kasus 10 (sepuluh) tahun terakhir,yang dikutip dari news.detik.com tanggal 21 Juli 2010, bahwa ada seorang pensiunan guru di Jombang Jawa timur yang tewas setelah melakukan pengobatan tradisional bekam di rumah Siti Mufritah yang bekerja sebagai ahli bekam. Siti Mufritah yang telah puluhan tahun membuka praktik bekam dirumahnya di desa Pundong Jombang Jawa Timur inipun langsung berurusan dengan kepolisian.

Kasus di atas merupakan kasus yang telah dilakukan oleh orang selain tenaga kesehatan yang tidak mempunyai latar belakang pendidikan kesehatan, tetapi diperoleh dari pelatihan-pelatihan maupun mewarisi bakat turun temurun dari keluarganya. Kasus di atas bisa saja menimpa perawat yang melakukan pelayanan komplementer-alternatif dalam praktik keperawatan mandirinya. Apabila perawat lalai dan kurang berhati-hati dalam melaksanakan pelayanan komplementer dan alternatif, dapat dipastikan bahwa hal serupa akan terjadi, mengingat hadirnya terapi komplementer saat ini masih menimbulkan kontroversial tentang etis tidaknya apabila diterapkan dalam layanan kesehatan. Di samping itu batasan standar prosedur operasional pada pelayanan komplementer-alternatif juga belum terdeskripsi secara jelas. Sampai sejauh ini memang belum ada kasus perawat yang dipidanakan karena melakukan pengobatan komplementer-alternatif namun perawat tetap harus berhati-hati dan waspada dalam menjalankan kewenanganya sebagai perawat yang melakukan pengobatan komplementer-alternatif. Walau demikian, tidak selamanya teknik pengobatan komplementer itu membahayakan pasien, asalkan dapat dipraktikkan oleh tenaga kesehatan yang profesional dan orang-orang yang telah memiliki lisensi ijin praktik resmi yang dapat dipertanggung jawabkan keamananya.

\subsection{Rumusan Masalah}

Berdasarkan latar belakang di atas yang menjadi rumusan masalah dalam penelitian ini adalah sebagai berikut:

1. Bagaimana kewenangan perawat dalam pengobatan bekam pada praktik keperawatan mandiri.

2. Bagaimana perlindugan hukum pengobatan bekam pada praktik keperawatan mandiri.

\section{KAJIAN PUSTAKA}

\subsection{Kewenangan}

Dalam Black Law Dictionary kewenangan diartikan lebih luas, tidak hanya melakukan praktik kekuasaan, tetapi kewenangan juga diartikan dalam konteks menerapkan dan menegakan hukum, adanya ketaatan yang pasti, mengandung perintah, memutuskan, adanya pengawasan yuridiksi bahkan kewenangan di kaitkan dengan kewibawaan, charisma, dan bahkan kekuatan fisik.

Menurut Bagir Manan dalam Ridwan HR, wewenang dalam bahasa hukum tidak sama dengan kekuasaan (macht). Kekuasaan hanya menggambarkan hak untuk berbuat atau tidak berbuat.

Menurut P. Nocolai kewenangan berkaitan dengan kemampuan untuk melakukan perbuatan hukum tertentu [yaitu tindakan-tindakan yang dimaksudkan untuk menimbulkan akibat hukum, dan mencakup mengenai timbul dan lenyapnya akibat hukum, sedangkan kemampuan berkaitan erat dengan kompetensi.

\subsection{Pengobatan Bekam}

Bekam merupakan salah satu pelayanan kesehatan tradisional yang sedang berkembang di masyarakat Indonesia. Bekam sudah dikenal sejak zaman dulu. Pada zaman Nabi Muhammad, beliau menggunakan tanduk kerbau atau sapi, tulang unta, gading gajah. 
Adapun masyarakat pada zaman Cina kuno menyebut hijamah sebagai "perawatan tanduk" karena tanduk menggantikan kaca. Sementara itu, orang-orang di Eropa menggunakan lintah sebagai alat untuk hijamah. Dalam artikelnya, Curtis mengemukakan bahwa bekam sudah ada di dalam catatan kedokteran tertua (Papyrus Ebers), yang ditulis 1550 SM pada era Mesir kuno.

Bekam dapat digunakan sebagai terapi untuk gangguan menstruasi, demam, gangguan nafsu makan dan berbagai macam nyeri. Selain itu, bekam juga merupakan terapi suportif untuk mempercepat proses penyembuhan penyakit.

Pengobatan bekam terbagi menjadi dua jenis, yakni bekam basah dan bekam kering. Bekam kering mencakup bekam luncur, bekam api, dan bekam tarik. Yang membedakan antara bekam basah dan bekam kering, adalah ada tidaknya darah yang dikeluarkan. Teknik bekam luncur dilakukan dengan meng-kop bagian tubuh tertentu, lalu meluncurkan kop tersebut ke bagian tubuh yang lain. Sedangkan bekam tarik dilakukan dengan cara meng-kop beberapa detik kemudian kop ditarik dan ditempelkan kembali pada kulit.

Pada proses terapi pembekaman, terjadi bendungan lokal, di mana stimulasi titik meridian, menyebabkan hipoksia dan radang, sehingga dapat memperbaiki mikrosirkulasi dan fungsi sel dengan cepat. Lima belas hari setelah terapi bekam, terjadi peningkatan elastisitas spektrin yang dapat menstimulasi kerja sistem kekebalan tubuh: sel pembunuh alami (Natural Killer cells), sehingga daya tahan tubuh meningkat baik sebagai pencegahan maupun perlawanan terhadap penyakit. Meridian atau potent points merupakan suatu sistem saluran yang membujur dan melintang di seluruh tubuh yang secara kedokteran tidak terlihat nyata tetapi dapat dibuktikan keberadaannya dengan radioaktif teknesium perteknetat, yang menghubungkan permukaan tubuh dengan organ dalam tubuh, organ satu dengan organ lainnya, organ dengan jaringan penunjang-jaringan penunjang lainnya, sehingga membentuk suatu kesatuan yang bereaksi bersama apabila ada rangsangan dari kulit.

\subsection{Praktik Keperawatan Mandiri}

Menurut Undang-Undang No.38 Tahun 2014 tentang Keperawatan yang disebut praktik keperawatan adalah pelayanan yang diselenggarakan oleh perawat dalam bentuk asuhan keperawatan. Asuhan keperawatan itu sendiri merupakan rangkaian interaksi perawat dengan klien dan lingkunganya untuk mencapai tujuan pemenuhan kebutuhan dan kemandirian klien dalam merawat dirinya. Sedangkan menurut PPNI, Praktik keperawatan adalah tindakan pemberian asuhan keperawatan profesional baik secara mandiri maupun kolaborasi yang disesuaikan dengan lingkup wewenang dan tanggung jawab berdasarkan ilmu keperawatan.

Mandiri adalah keadaan dapat berdiri sendiri, tidak bergantung dengan orang lain, dan mampu memberikan keputusan terhadap suatu masalah dalam usahanya secara personal.

Praktik keperawatan mandiri adalah praktik perorangan atau berkelompok di tempat praktik mandiri di luar Fasilitas Pelayanan Kesehatan (Fasyankes). Praktik keperawatan mandiri diberikan dalam bentuk asuhan keperawatan yang bertujuan utuk memandirikan klien yang membutuhkan bantuan karena ketidaktahuan, ketidakmampuan, dan ketidakmauan memenuhi kebutuhan dasar dan merawat dirinya.

Praktik keperawatan mandiri adalah Fasilitas Pelayanan Kesehatan Perorangan milik perawat yang didirikan untuk menjalankan asuhan keperawatan secara mandiri dalam lingkup UKP (Upaya Kesehatan Perorangan).

\section{METODE PENELITIAN}

Metode pendekatan yang digunakan dalam penelitian ini adalah pendekatan yuridis normatif, yaitu penelitian hukum yang dilakukan berdasarkan bahan hukum utama dengan cara menelaah teori-teori, konsep-konsep, asas-asas hukum serta peraturan perundang-undangan yang berhubungan dengan penelitian ini. Peneliti memilih melakukan metode ini dengan pertimbangan karena situasi yang masih terkendala Covid-19 jika penelitian tersebut dilakukan dengan pendekatan empiris. Tipe desain penelitian yang digunakan adalah Descriptive Design. Teknik pengumpulan data dalam penelitian ini dilakukan dengan cara pengumpulan data sekunder yaitu 
yang diperoleh melalui kepustakaan dan juga sumber hukum perundang-undangan. Selanjutnya data dianalisis menggunakan teknik analisis kulitatif, yaitu untuk menjawab permasalahan bagaimana kewenangan perawat dalam pengobatan bekam pada praktik keperawatan mandiri, dan bagaimana perlindugan hukum pengobatan bekam pada praktik keperawatan mandiri.

\section{HASIL DAN PEMBAHASAN}

\subsection{Kewenangan Perawat dalam Pengobatan Bekam pada Praktik Keperawatan Mandiri}

Kewenangan merupakan kekuasaan formal yang berasal dari undang-undang, sedangkan wewenang adalah suatu spesifikasi dari kewenangan, artinya barang siapa (subyek hukum) yang diberikan kewenangan oleh undang-undang, maka ia berwenang untuk melakukan sesuatu yang tersebut dalam kewenangan itu.

Dalam hukum publik, wewenang berkaitan dengan kekuasaan. Kekuasaan memiliki makna yang sama dengan wewenang karena kekuasaan yang dimiliki oleh Eksekutif, Legislatif dan Yudikatif adalah kekuasaan formal. Kekuasaan merupakan unsur esensial dari suatu negara dalam proses penyelenggaraan pemerintahan di samping unsur-unsur lainnya.

Kekuasaan untuk menetapkan batasan alternatif-alternatif bertindak bagi seseorang atau sekelompok orang dalam kehidupan masyarakat pada dasarnya adalah pembuatan aturanaturan hukum sebagai aturan main dalam kehidupan masyarakat yang disertai dengan sanksi hukum tertentu untuk menjamin terselenggaranya ketertiban dan ketenteraman dalam hubungan-hubungan sosial. Kekuasaan adalah kemampuan umum untuk menjamin pelaksanaan dari kewajiban-kewajiban yang mengikat oleh unit-unit organisasi kolektif dalam suatu sistem yang merupakan kewajiban-kewajiban yang diakui dengan acuan kepada pencapaian tujuan-tujuan kolektif mereka dan bila ada pengingkaran terhadap kewajibankewajiban dapat dikenai oleh sanksi negatif tertentu siapapun yang menegakkannya.

Dari konsep di atas, jika ditarik ulur maka diperoleh rumus bahwa kewenangan merupakan kekuasaan yang diperoleh subjek hukum atas dasar kemampuan yang dimiliki untuk menjalankan suatu wewenang tersebut sedangkan kemampuan sendiri berkaitan erat dengan kompetensi.

Wibowo, menyebutkan bahwa kompetensi adalah suatu kemampuan untuk melaksanakan atau melakukan suatu pekerjaan atau tugas yang dilandasi atas keterampilan dan pengetahuan serta didukung oleh sikap kerja yang dituntut oleh pekerjaan tersebut. Dengan demikian, kompetensi menunjukkan keterampilan atau pengetahuan yang dicirikan oleh profesionalisme dalam suatu bidang tertentu sebagai sesuatu yang terpenting, sebagai unggulan bidang tertentu, dengan indikatornya adalah; pengetahuan, ketrampilan dan sikap. Sedangkan Moh. Uzer Usman menyebutkan bahwa, seseorang disebut kompeten apabila telah memiliki kecakapan bekerja pada bidang tertentu dari hal ini maka kompetensi juga diartikan sebagai suatu hal yang menggambarkan kualifikasi atau kemampuan seseorang, baik yang kualitatif maupun kuantitatif.

Kompetensi diporeh dari:

Formal (Pendidikan dari Perguruan Tinggi)

Non Formal (Pelatihan, Warisan, dan Tradisi).

Terkait dengan pengobatan bekam, Bekam merupakan pengobatan rakyat atau pengobatan tradisional yang digunakan sebagai salah satu jenis terapi komplementer atau alternatif yang telah banyak dipraktikkan di seluruh dunia. Bekam merupakan salah satu intervensi medis tertua yang dipercaya ada sejak 3000 sebelum masehi. Catatan paling awal tentang bekam adalah dalam Ebers Papyrus, salah satu buku teks kedokteran tertua di dunia. Buku ini menuliskan bahwa bekam telah ada di Mesir pada tahun 1.550 tahun sebelum masehi (SM) dengan mekanisme kerja membuang zat asing dari dalam tubuh. Dari ketentuan ini saja sudah jelas bahwa bekam merupakan warisan leluhur, dan tradisi turun temurun dalam bidang pengobatan alternatif. Hal ini sudah jelas bahwa pengobatan bekam merupakan Pendidikan non formal melalui warisan dan tradisi. Di samping itu juga telah banyak organisasi-organisasi yang menyelenggarakan pelatihan bekam seperti; Perkumpulan Induk Organisasi Kesehatan 
Tradisional Indonesia (PIKTI), Perhimpunan Ahli Bekam Sunah Indonesia (PABSI), Perkumpulan Bekam Indonesia, dan lain sebagainya yang juga mengeluarkan sertifikasi keahlihan di bidang bekam.

Disamping itu, pada Pasal 21 ayat (1) huruf m Permenkes No. 26 tahun 2019 Tentang Peraturan Pelaksanaan Undang-Undang Nomor 38 Tahun 2014 Tentang Keperawatan, disebutkan bahwa dalam menjalankan tugas sebagai pemberi Asuhan Keperawatan di bidang upaya kesehatan masyarakat, Perawat berwenang melakukan penatalaksanaan Keperawatan komplementer dan alternatif. Yang mana komplementer dan alternatif sebagaimana yang disampaikan oleh Ketua Himpunan Perawat Holistik Indonesia, bahwa bidang keperawatan ini meliputi; bekam, akupresur, hipnoterapi, dan herbal. Disamping itu, pada Pasal 21 ayat (1) huruf $m$ jika dikaitkan dengan Pasal 30 tentang keadaan tertentu dapat dimaknai bahwa perawat selain melakukan pengobatan bekam juga dapat melakukan pengobatan untuk penyakit umum dalam hal tidak terdapat tenaga medis. Meskipun ketentuan ini dihadang dengan bunyi ayat (1), (2) dan (3) yang mengatakan bahwa kewenangan yang merupakan penugasan Pemerintah ini ditetapkan oleh Kepala Dinas Kesehatan Pemerintah Daerah kabupaten/kota dengan memperhatikan kompetensi Perawat dan telah mengikuti orientasi dan/atau pelatihan.

Sampai sejauh ini belum ada peraturan tentang keadaan keterbatasan tertentu yang dikeluarkan oleh kepala Satuan Kerja Perangkat Daerah yang menyelenggarakan urusan pemerintahan di bidang kesehatan setempat sehingga berlaku asas Nullum delictum nulla poena sine praevia lege poenali, yang artinya, tiada suatu perbuatan dapat dihukum, kecuali atas kekuatan dalam ketentuan pidana dalam UU yang telah ada lebih dahulu daripada perbuatan itu. Jadi meskipun tanpa perintah penugasan Pemerintah, perawat tetap dapat menjalankan keadaan keterbatasan tersebut mengingat bahwa tujuan pengobatan ini juga ditujukan untuk meningkatkan derajat kesehatan masyarakat demi mendukung terwujudnya pembangunan kesehatan Pemerintah melalui pelayanan primer.

Berdasarkan hasil analisis di atas, peneliti menyimpulkan bahwa perawat memiliki kewenangan dalam melakukan pengobatan bekam yang diperoleh dari pendidikan non formal. Perawat berwenang melakukan pengobatan asalkan perawat tersebut memiliki kompetensi di bidang yang dimaksud dan mampu membuktikan kepada masyarakat, organisasi profesi serta Pemerintah melalui sertifikasi kompetensi yang dimiliki. Suatu kompetensi jika tidak dapat dibuktikan dengan sertifikasi maka tidak akan ada gunanya, sebaliknya jika memiliki sertifikasi namun tidak berkompeten juga akan sia-sia saja, sehingga kedua hal ini harus saling dilengkapi bagi perawat yang melakukan pengobatan bekam pada praktik keperawatan mandiri. Hal ini dimaksudkan untuk mencegah hal-hal yang tidak diduga dan tidak di inginkan dalam pelayanan asuhan keperawatan.

\subsection{Perlindungan Hukum Pengobatan Bekam pada Praktik Keperawatan Mandiri}

Satjipto Raharjo menyatakan bahwa, perlindungan hukum adalah memberi pengayoman terhadap Hak Asasi Manusia (HAM) yang dirugikan orang lain dan perlindungan itu diberikan kepada masyarakat agar dapat menikmati semua hak-hak yang diberikan oleh hukum.

Menurut Soedikno Mertokusumo, perlindungan hukum adalah jaminan hak dan kewajiban manusia dalam rangka memenuhi kepentingan sendiri maupun di dalam hubungan manusia.

Menurut Sukendar dan Santoso, sarana perlindungan hukum dibagi menjadi 2 (dua) macam, yaitu:

a. Perlindungan hukum preventif adalah langkah atau cara yang dilakukan untuk mencegah suatu kejadian yang berakibat hukum.

b. Perlindungan hukum represif adalah langkah atau cara yang dilakukan apabila suatu kejadian yang berakibat hukum itu telah terjadi.

Perlindungan hukum kepada masyarakat selalu berkaitan erat dengan kekuasaan Lembaga Negara yang meliputi: 
a. Legislatif yang bertugas membuat undang undang. Lembaga legislatif meliputi Dewan Perwakilan Rakyat (DPR), DPD, MPR.

b. Eksekutif yang bertugas menerapkan atau melaksanakan undang-undang. Lembaga eksekutif meliputi presiden dan wakil presiden beserta menteri-menteri yang membantunya.

c. Yudikatif yang bertugas mempertahankan pelaksanaan undang-undang. Lembaga yudikatif terdiri atas Mahkamah Agung (MA), Mahkamah Konstitusi (MK), dan Komisi Yudisial.

Perlindungan hukum bagi warga negara dari tindakan pemerintahan pada prinsipnya memiliki tujuan sebagai berikut:

a. Perlindungan hukum dalam rangka menjamin terpenuhinya hak-hak warga negara.

b. Perlindungan hukum dalam rangka mencegah terjadinya tindakan yang merugikan hak-hak warga negara.

c. Perlindungan hukum menyediakan akses bagi warga negara untuk menghentikan tindakan pelanggaran, mendapatkan ganti kerugian atau tindakan pemulihn atas pelanggaran haknya.

d. Perlindungan hukum dalam menjamin tersedianya ganti kerugian atautindakan pemulihan terhadap hak warga negara yang telah dirugikan.

Sebagai bentuk perlindungan hukum kepada perawat yang melakukan pengobatan bekam pada praktik keperawatan mandiri, sebenarnya hal tersebut sudah terlihat dalam upaya hukum preventif yang dibuat oleh Lembaga Negara, yakni; UU No. 38/ 2014, dan Permenkes No. 26/2009.

Selain yang peneliti sampaikan di atas, sebagai bentuk perlindungan hukum bagi perawat, Dinkes Kab/Kota juga telah melakukan pembinaan dan pengawasan dalam menjamin keselamatan pasien dalam pelayanan komplementer-alternatif pada praktik keperawatan mandiri. Melalui Organisasi Profesi yang merupakan perwakilan dari Dinas Kesehatan, bertugas melakukan monitoring terhadap kendala-kendala yang dihadapi perawat dalam menjalankan UKP (Upaya Kesehatan Perorangan). Hal ini ditujukan untuk melakukan pencegahan terhadap risiko terjadinya malpraktik. Apabila terjadi dugaan malpraktik, maka harus diselesaikan terlebih dahulu dengan mediasi. Dinas Kesehatan pasti juga memastikan bahwa perawat yang melakukan pelayanan komplementer-alternatif pada praktik keperawatan mandiri bertanggungjawab sepenuhnya terhadap pelayanan yang diberikan. berbunyi:

Sebagaimana Pasal 36 huruf a UU No. 38 tahun 2014 tentang Keperawatan yang

"Perawat dalam melaksanakan Praktik Keperawatan berhak memperoleh pelindungan hukum sepanjang melaksanakan tugas sesuai dengan standar pelayanan, standar profesi, standar prosedur operasional, dan ketentuan Peraturan Perundangundangan".

Kemudian Pasal 58 ayat (2) UU No. 38 tahun 2014 tentang Keperawatan berbunyi:

"Setiap orang yang tidak memiliki STR, tidak memiliki SIPP, tidak memasang papan nama praktik keperawatan mandiri, tidak memiliki kompetensi, akan dikenakan sanksi administratif berupa; teguran lisan, peringatan tertulis, denda administratif, dan pencabutan izin".

Berdasarkan hasil analisis di atas, peneliti menyimpulkan bahwa perawat dalam transaksi terapeutik di bidang pelayanan kesehatan dilindungi oleh pemerintah melalui peraturan perundang-undangan yang berlaku bagi pelaksana keperawatan. Pasien yang menerima pengobatan bekam juga mendapatkan jaminan keselamatan sebagaimana tercantum dalam Pasal 58 ayat (1) UU No. 36 tahun 2009 tentang Kesehatan yang berbunyi:

"Setiap orang berhak menuntut ganti rugi terhadap seseorang, tenaga kesehatan, dan/atau penyelenggara kesehatan yang menimbulkan kerugian akibat kesalahan atau kelalaian dalam pelayanan kesehatan yang diterimanya". 


\section{KESIMPULAN}

Dari seluruh hasil pembahasan yang telah dipaparkan, peneliti menyimpulkan:

1. Bahwa perawat memiliki kewenangan dalam melakukan pengobatan bekam yang diperoleh dari pendidikan non formal. Perawat berwenang melakukan pengobatan asalkan perawat tersebut memiliki kompetensi di bidang yang dimaksud dan mampu membuktikan kepada masyarakat, organisasi profesi serta Pemerintah melalui sertifikasi kompetensi yang dimiliki. Suatu kompetensi jika tidak dapat dibuktikan dengan sertifikasi maka tidak akan ada gunanya, sebaliknya jika memiliki sertifikasi namun tidak berkompeten juga akan sia-sia saja, sehingga kedua hal ini harus saling dilengkapi bagi perawat yang melakukan pengobatan bekam pada praktik keperawatan mandiri. Hal ini dimaksudkan untuk mencegah hal-hal yang tidak diduga dan tidak di inginkan dalam pelayanan asuhan keperawatan.

2. Bahwa perawat dalam transaksi terapeutik di bidang pelayanan kesehatan mendapatkan pengayoman hukum secara preventif yaitu dilindungi oleh lembaga-lembaga negara melalui peraturan perundang-undangan yang berlaku bagi pelaksana keperawatan. Pasien yang menerima pengobatan bekam juga mendapatkan jaminan keselamatan sebagaimana tercantum dalam Pasal 58 ayat (1) UU No. 36 tahun 2009 tentang Kesehatan.

\section{DAFTAR PUSTAKA}

\section{BUKU}

Aris Prio Agus Santoso, 2019, Tesis: Analisis Yuridis Kewenangan Perawat Dalam Pelayanan Komplementer-Alternatif Pada Praktik Keperawatan Mandiri, Semarang: Universitas Katolik Soegijapranata.

2020, Hukum Kesehatan, Jakarta: Trans Info Media.

2020, Hukum Administrasi Negara, Yogyakarta: Pustaka Baru Press.

2020, Hukum Kesehatan (Pengantar Program Studi Sarjana Hukum), Yogyakarta:

Pustaka Baru Press.

Burhan Ashsofah, 2010, Metode Penelitian Hukum, Jakarta: Rineka Cipta.

Daryanto, 1997, Kamus Bahasa Indonesia Lengkap, Surabaya: Apollo.

Dirjen Yankestrad Kemenkes, 2016, Laporan Akuntabilitas Kinerja Direktorat Bina Pelayanan Kesehatan Tradisional, Alternatif dan Komplementer Tahun 2016, Jakarta: Kemenkes. DPP PPNI, 2017, Pedoman Praktik Keperawatan Mandiri, Jakarta : DPP PPNI.

Gerardus Gegen, dan Aris Prio Agus Santoso, 2019, Etika Profesi Keperawatan dan Hukum Kesehatan, Jakarta: Trans Info Media.

Ridwan HR, 2014, Hukum Administrasi Negara, Jakarta: Rajawali Pers. -, 2014, Diskresi dan Tanggungjawab Pemerintah, Yogyakarta: FH UII Press.

Hapsara HR, 2016, Penguatan Upaya Kesehatan Masyarakat dan Pemberdayaan Masyarakat Bidang Kesehatan di Indonesia, Yogyakarta: Gadjah Mada University Press.

Sahya Anggara, 2018, Hukum Administrasi Negara, Bandung: Pustaka Setia.

Salim dan Erlies, 2013, Penerapan Teori Hukum pada Penelitian Tesis dan Disertasi, Jakarta: Rajawali Pers

-------------, 2017, Penerapan Teori Hukum, Jakarta: Rajawali Pers.

Satjipto Rahardjo, 2000, Ilmu Hukum, Bandung: Citra Aditya Bakti.

Soedikno Mertokusumo, 1991, Mengenal Hukum (Suatu Pengantar), Yogyakarta: Liberty.

Soekidjo Notoatmojo, 2010, Etika dan Hukum Kesehatan, Jakarta: Rineka Cipta.

Sugiyono, 2010, Statistik Untuk Penelitian. Bandung: Alfabeta .

Universitas Katolik Soegijapranata, 2015, Petunjuk Penulisan Usulan Penelitian dan Tesis, Semarang: Prodi Magister Ilmu Hukum Universitas Katolik Soegijapranata.

Titik Triwulan, dan Shinta Febran, 2010, Perlindungan Hukum bagi Pasien, Jakarta: Prestasi Pustaka.

Zainudin Ali, 2010, Metode Penelitian Hukum, Jakarta: Sinar Grafika.

\section{JURNAL ILMIAH}


Aris Prio Agus Santoso, dan Erna Chotidjah Suhatmi, "Pemutusan Hubungan Kerja Di Tengah Pandemi Covid-19 Ditinjau Dari Sudut Pandang Hukum Ketenagakerjaan”, UNIFIKASI: Jurnal Ilmu Hukum, Vol. 8, No. 1, 2021.

Aris Prio Agus Santoso, et.all, "Analisis Yuridis Pemberian Upah di Bawah UMK Bagi Tenaga Kesehatan di Rumah Sakit”, JISIP (Jurnal Ilmu Sosial dan Pendidikan), Vol. 5, No. 3, 2021.

Aris Prio Agus Santoso, dan Tatina Siska Wardani, "Analisis Yuridis Kewenangan Perawat Dalam Pemberian Obat-Obatan Label Merah Pada Praktik Keperawatan Mandiri”, Yurisprudentia: Jurnal Hukum Ekonomi, Vol. 6, No. 1, 2020.

Aris Prio Agus Santoso, et.all, "Legal Protection of Health Workers in the Task Force for the Acceleration of Handling Covid-19 from a State Administrative Law Point of View", Jurnal Ilmu Sosial dan Ilmu Pendidikan, Vol. 5, No. 2, 2021.

Aryono, Rina Arum Prastyanti, "Protection Of Children From Violence In Social Media In The New Normal Era", Veteran Justice Journal, 2, No. 1, 2020.

Hanik Badriyah Hidayati, dkk, "Bekam Sebagai Terapi Alternatif Untuk Nyeri", Neurona Vol. 36, No. 2, 2019.

Lestari Dewi, Muhammad Jamhari, dan Isnainar, "Kajian Tanaman Pemanfaatan Obat Sebagai Obat Tradisional Di Desa Tolai Kecamatan Torue Kabupaten Parigi Moutung”, Jurnal Vol. 5 No. 2, 2017.

Salman Luthan, “Dialektika Hukum dan Kekuasaan”, Jurnal Hukum, Vol. 7, No. 14, 2000.

Oktavia Eko Anggraini, Windy Ratna Yulifa, dan Aris Prio Agus Santoso, "Perlindungan Hukum Bagi Konsumen Atas Garansi Produk Dalam Hukum Bisnis”, Call For Paper HUBISINTEK, Vol. 1, 2020.

Muhammad Ridwan Adhitya, Nurika Suci Wulan, Putri Nur Azizah, dan Aris Prio Agus Santoso, "Legal Protection Of Women Victims Of Domestic Violence In Terms Of Human Rights (Normative Study Of The Surakarta Case Area)”, IJLLE, Vol. 1, No. 2, 2020.

Widyatuti, "Terapi Komplementer Dalam Keperawatan” Jurnal Keperawatan Indonesia, Vol. 22, No. 1, 2008.

Yenni Risniati, dkk, "Pelayanan Kesehatan Tradisional Bekam: Kajian Mekanisme, Keamanan dan Manfaat ", Jurnal Penelitian dan Pengembangan Pelayanan Kesehatan, Vol. 3, No. 3, 2019.

\section{PERATURAN}

RI, Undang-Undang Dasar tahun 1945.

RI, Undang-Undang No. 36 tahun 2009 tentang Kesehatan.

RI, Undang-Undang No. 36 tahun 2014 tentang Tenaga Kesehatan..

RI, Peraturan Menteri Kesehatan No. 26 tahun 2019 Tentang Peraturan Pelaksanaan UndangUndang Nomor 38 Tahun 2014 Tentang Keperawatan. 